\title{
Changes, continuities, farewells, welcomes and grateful thanks
}

\section{Phillipp Schofield}

There has been more change on the masthead of this journal in recent years than there has been continuity. In the summer of 2011, Phillipp Schofield, a co-editor of Continuity and Change since 1999, stepped down as Editor before moving over to edit Economic History Review. Neither journal can be faulted for its choice. But I am pleased to say that we discovered Phillipp first, and we hope and expect that his association with the journal will continue.

Phillipp's appointment as Editor was to replace our de facto third editor, Professor (now Dean) L. R. Poos. To the outsider it must have appeared to be a natural exchange; English medievalist, a social and economic historian, with a nod towards the legal, for a scholar with similar interests. In many ways it was; but, no two academics, regardless of background and inclination, are identical. Moreover, the demands of the journal had changed. The formative years of the journal were behind it. Reliance on the troika of Wall-Bonfield-Poos, ghostwriters for numerous solicited articles authored by our non-native English-speaking colleagues, was no longer necessary. Articles began to flow spontaneously, not relentlessly as they now seem to do, but in adequate numbers. Continuity and Change had fully arrived.

What was required was a manager, and Phillipp, as well as bringing his intellectual credentials to the journal, satisfied that need. Interesting additions to our twice-yearly editorial meetings, such as lists of articles 
submitted, appeared. Likewise, the editors began to understand that there were actually processing timetables. The journal began to appear in print as scheduled, sometimes even scandalously preceding the date emblazoned on the cover.

Phillipp's contributions went considerably farther, however. When he joined us as Editor, Phillipp's career was in the prime of the second age while that of Richard and my own were entering the third. His energies seemed boundless just as ours were flagging. The journal owes many a special issue to conferences that Phillipp organised or attended around the globe. The journal had found an editor we could envisage as a successor, and a change of the guard would probably have naturally transpired had Richard and I not enjoyed working with Phillipp so much: we never wanted to leave because working with him was just too much 'fun' and I am looking forward to continue working with him as colleagues on the Editorial Board.

LLOYD BONFIELD

It can be intimidating joining the well-established crew of a renowned ship, and I felt very much the novice when invited to become one of the editors of Continuity and Change. In Phillipp, however, I could not have found a more helpful and considerate mentor. I will always be grateful for his patience and guidance while I found my feet and, while wishing him every success in his new post as Editor of Economic History Review, I am very glad he has agreed to retain his connection with Continuity and Change and become a member of the Editorial Board. Good luck for the future and thank you, Phillipp, for all you have done for the journal!

Grateful thanks are also due to the members of the Editorial Board who have come to the end of their allotted period of tenure, and to those who have chosen to step down at this time. The work of Elizabeth Bright Jones, Elizabeth Foyster, Steve Hoch, Edward Purcell, Marlou Schrover, Jan Luiten van Zanden, Frank Towers and Monique Bourin on the journal's behalf over the years has been very much appreciated and everyone at the journal wishes them all well for the future.

As leave is taken of 'old' friends a warm welcome is extended to their successors. Svetla Baloutzova, Jeremy Boulton, Chris Briggs and Tom Gallanis have all agreed to (re)join the Editorial Board and have already begun reading, commenting on and, where appropriate, reviewing 
anonymous versions of the healthy stream of papers we have recently been receiving. Beatrice Moring too, despite her recent loss, has agreed to join the Editorial Board in addition to her role as Production Manager. Her continued presence, along with that of Antoinette Fauve-Chamoux, Antoni Furió, Satomi Kurosu, Camen Sarasua García, Tom Sokoll, Erik Thoen and, of course, Lloyd and Phillipp, is a very welcome continuity in this time of change.

Last, but by no means least, Mary Louise Nagata and Julie Marfany deserve a great deal of thanks for agreeing to step into the huge breach left by Richard, Lloyd and now Phillipp. Their names now appear as Editors on the masthead on the inside cover of this latest edition of the journal, and their addresses, the destination for new submissions, are listed on the inside of the back cover. It is hoped they will remain there for some time to come, as the three 'new' Editors look forward to receiving the flow of papers built up by our predecessors and carrying Continuity and Change into the future in the spirit in which it was founded. 